\title{
Relational Capital: An Imperative for Effective Service Localization
}

\author{
Kuroakegha Basuo \\ Department of Business Administration, Niger Delta University, Wilberforce Island Yenegoa, Bayelsa State, \\ Nigeria
}

\begin{abstract}
This paper addressed the relationship between relational capital and effective service localization. As a review, the paper discussed literature on three main concepts - relational capital, service localization and effective service localization. Effort was made to distinguish between service localization and effective service localization of telecom multinationals in Nigeria. The findings reveal that a generality of studies identify relational capital as providing the required knowledge-base and resources for effectively localizing firm's services. In conclusion it was stated that relational capital is imperative and enhances the extent to which firms are able to understand and appreciate the uniqueness of their foreign operational contexts, meet with the social and economic requirements of such a context and as such be consistent in their service to their foreign markets or operational contexts
\end{abstract}

Keywords: Relational capital, effective, service localization, multinationals, foreign direct investments, telecommunication

DOI: $10.7176 /$ EJBM/11-11-09

Publication date: April $30^{\text {th }} 2019$

\section{Introduction}

Foreign direct investments (FDI) are noted for their exposure to additional environmental risk or operating cost factors prevalent in host countries. Elango (2009) observed that poor investment outcomes include inefficient business systems, distraught employees or staff, poor relations with external stakeholders (e.g. government agencies) and consistent conflict with host communities leading to service disruptions and loss of investments. Thus, suggesting a significant disconnect between the business and its environment (Habib \& Zurawicki, 2002; Gertler, 2003). There is therefore the need for stronger networking activities, partnerships and collaboration platforms in ensuring a more effective localization of firms' services.

In Nigeria, certain legal and socio-cultural frameworks guide and structure business activities of which telecom multinationals are not exempted (Izuchukwu, 2014; Eme \& Onwuka, 2011). The Nigerian telecommunication sector is considered a highly competitive sector and also anchors as a major revenue generating sector for both host and home country of multinationals (Izuchukwu, 2014). Unfortunately, reports of conflict between host communities and telecom multinationals, as well as ligations against some of these firms suggest a growing disparity in expectations with regards to services and business boundaries (Hassan, 2011).

Such disparities are revealed to be detrimental to the functionality or performance of these firms, and in most cases, contribute to the shutdown of branches in conflict zones, as well as staff redundancy. These challenges have been traced by a number of scholars and professionals to multinational's poor community relations as well as the over stretching of business boundaries for economic or market gain (Izuchukwu, 2014; Hassan, 2011). Hennart (2012) noted that by building stronger network ties, engaging more local business partners and collaborating with local authorities, all of which reflect relational capital, multinationals can enhance their local market positions and as such, effectively localize their services.

While, extant literature on service localization has focused on service characteristics such as language, marketing features and technology (Jensen, 2006; Christensen, 1997; Andersson, Forsgren \& Holm, 2002). There is however a gap in literature examining the role of relational capital in the effective localization of services. This is as the effective localization of services entails far more than just the features and technological configurations of services (Coleman, 1988; Kale, Dyer \& Singh, 2002; Brouthers \& Hennart, 2007); hence, not much study has addressed relational capital factors such as partnerships and collaboration with local authorities and the extent to which these contribute towards the effective localization of services in foreign economies or nationalities.

This study therefore departs from previous theoretical positions as it examines the operational relationship between relational capital and effective service localization, with particular reference to telecom multinationals operating in Nigeria. The study addresses this relationship based on the following objectives:

i. This study discussed the conceptualizations and features of three main concepts - relational capital, service localization, and effective service localization

ii. An attempt was also made to distinguish between service localization and effective service localization

iii. Finally, a theoretical link is attempted between relational capital and effective service localization 


\section{Institutional Theory}

This position of this paper on the relationship between relational capital and effective service localization is premised on the prescriptions of the institutional theory. Acemoglu and Johnson (2005) described the institutional theory as that which emphasizes on organizational behavioural modifications in line with norms and cultural values of the society. Its stresses the need for organizations to conform as a basis for performance or effectiveness. Conformity to operational standards, societal or market norms, values and ideologies facilitate more support and access to the organization from its environment and from significant others within its operational context (Andersen, 2013; Henisz, 2000).

The institutional theory identifies conformity in organizational behaviour with its capacity for effectiveness within contexts that offer dissimilar social settings and unique social attributes (Peng, 2003). The prevailing unique features and attributes of each context offer organizations a variety of expectations across several contexts as no two contexts are considered as exactly the same, with each context imposing specific constraints on the behaviour or actions of the organization. Thus, legitimacy is attained based on the degree to which macro-cultural values and social conventions are observed and respected by the organization as well as its streamlining of activities with regards to the legal frameworks of the society (Andersen, 2013). In this way, actions which fall beyond or which fail to conform to stated frameworks are considered as deviant and often discouraged.

The implications of the institutional theory for this paper are as follows:

i. The theory identifies the uniqueness of contexts and the variety of expectations each context bears upon organizations that operate within its specific boundaries

ii. The theory specifies the need for conformity as a means of ensuring effectiveness; thus, identifying the trustworthiness of network members as necessary in securing support and advantage from significant others. This is a core argument in the relational capital theory and advances the position of relationships and the benefits they serve the organization

iii. The theory emphasizes on reciprocity; thus, by adhering and conforming to the norms and business standards recognized and accepted within the society, the organization is afforded business opportunities and access to resources.

iv. The theory is wholistic and predictive in its approach towards explaining the nature of exchanges that occur between the organization and its environment (comprising its clients, vendors, competitors, regulating agencies, host communities and local authorities), by identifying the factors which shape and constrain business activities and behaviour within various contexts.

\section{Relational capital}

Numerous studies have described relational capital with definitions differing on substantial operational levels (Johnson, Cullen, Sakano \& Takenouchi, 1996; Butler, 1995). In this study, emphasis is placed on the content and advantages emerging from the organization's partnerships and networking, rather than the relationship itself. Relational capital as such describes those benefits and privileges accorded the organization as a result of its recognition and membership within clearly identifiable networks or groups.

Rindfleisch \& Moorman (2001) noted that relationships and business exchanges within particular markets offer organization a sense of placement and positioning. This is as their activities are hinged on a number of other structures and functions which pervade their markets and which define their roles and interactions within their various markets. Some roles and exchanges offer learning opportunities for organizations and enable their adoption of relevant models and structures, others facilitate access to resources and information considered as privy to a few.

Members within particular networks are more inclined to be cooperative and trusting of others within such networks and as such, willing to collaborate and engage in partnerships with them. Through collaborations and partnerships, organizations are able to share risks, generate relational rent, gain access to markets and acquire unique knowledge. Relational capital therefore goes beyond just the relationships and exchanges as it addresses the resources and advantages emergent from such relationships and the binding commitment and obligations imposed by it on its (network) members (Seviby, 2001; Speth, 2008; Zhang, Souitaris, Soh \& Wong, 2008).

In their study Vasileiadou and Missler-Behr (2010) affirmed that members of the same network and group often share a sense of responsibility towards each other. Their relationships offer shared constructs of the market and as such members readily draw on each other's experiences and operational models in addressing market and other socio-cultural related issues (Daum, 2003; Inkpen, 2002; Joshi \& Stump, 1999). These models may comprise of the supply or distribution nexus utilized by other organizations and which over time has facilitated their operational efficiency in their activities, or it may comprise of their relationships with key individuals within communities with strong influence over segments such as the youths, or market women. Such models can be made available to other organizations recognized as partners or collaborators, and can be adopted in addressing similar challenges or issues.

Although some scholars have approached relational capital from the position of actual exchanges and 
relationships such as distribution and supply channels (Starovic \& Marr, 2003), this paper aligns itself with the position of Nahapiet and Ghoshal, (1998) who described it as the result, advantages or benefits accruing from relationships and membership of networks. As such organizations are encouraged to actively seek out partnerships with other organizations considered as either older and more experienced, or locally grounded within foreign contexts; firms that could provide them with knowledge on the dynamics of the market and how to efficiently engage the market (Hyder \& Ghauri, 2000; Makino \& Delios, 1996)).

\section{Service Localization}

Service localization describes the process of adapting services and supporting systems to suit and address the needs or demands of a particular target market locale in such a way that locals are able to identify and utilize it such that it appears to have been developed there and for that locale alone (Cui, Meyer \& Hu, 2014; Delios \& Henisz, 2003). Service localization emphasizes on the reconfiguration of models and systems in a way that they accommodate details specific in addressing the unique demands and expectations of particular localities (Fryxell, Butler \& Choi, 2004; Guler \& Guillen, 2010).

In some cases, the process of localizing may entail the adoption of constraints or shedding off of features as a way of facilitating simpler user interfaces and applicable systems on local operational templates. In other cases, it may involve the upgrading of systems and software programmes to match service interfaces prevalent within the locality (Habib \& Zurawicki, 2002; Fryxell et al, 2004; Elango, 2009). From the foregoing, it is apparent that while dominant literature on service localization focuses on the features of the service itself and its accompanying systems, there are other factors which impose on the behaviour and functionality of the multinational corporation in its service localization. These factors mitigate the actions of the organization and impact on the receptivity, consistency or continuity of the firm in its provision of services. Hence the term - effectiveness of service localization.

\section{Effective Service Localization}

In the previous section, the concept of service localization was described, thus providing the required conceptual premise for the description of effective service localization. In this section, an attempt is made to a) distinguish between service localization and effective service localization, and b) expatiate on effective service localization. Building on the description of effectiveness by Zheng (2010), who referred to it (effectiveness) as the capacity of the firm to realize its goals through its interaction with the social and economic environment, this paper defines effective service localization as comprising those features adopted by the firm in its services which not only adapt its service features to the locality but also enable its adherence to social norms, specified legal frameworks, and cultural conventions (Chan, Isobe \& Makino, 2008; Zhao \& Anand, 2009; Young, Tsai, Wang, Liu \& Ahlstrom, 2014).

The major distinction herein is that while service localization specifies service features which adhere to the specific needs of the localities, effective service localization emphasizes on those actions and behaviour adopted by the multinationals which ensure that the localization of services is not thwarted or stifled. That is to say, those actions or behaviour focused on satiating the legal, social and cultural requirements of society from the firm, thereby ensuring the consistency of service and the achievement of service goals (Zheng, 2010; Holburn \& Zelner, 2010).

While, effectiveness ascribes to goal achievement and the assurance of service consistency, ineffectiveness on the other hand refers to outcomes such as a disruption of services, a shutdown of service units, litigations which impact on the functionality of the firms, or conflict between the firm and its host community. These factors, despite suitable and applicable service models and operational systems, often have a nullifying effect on the goals and objectives of service localization by multinational firms.

Effectiveness as applied herein implies consistency and the actual success of the service localization process as a result of its embeddedness within the system of laws, regulations, social as well as cultural conventions which define, guide and prevail over the local market and context (Elango, 2009; Cui, et al, 2014). One finds that while the development of service models and formats can be considered as successful within contrived work spaces or laboratories, it is the practical application and operationalization of such service models and formats within noncontextual settings which determine its effectiveness and substantiality.

This is as efforts geared towards addressing the effects of extraneous elements should also be considered as imperative and a prerequisite in the localization of services. Real success and effectiveness of service localization therefore addresses not only the features and characteristics of the service, but the prevailing conditions and contextual factors which may mitigate or affect its smooth running and application within its various localities. Hence, effective service localization offers a more encapsulating framework and premise in the assessment of service localization success (Roath, Miller \& Cavusgil, 2002).

Studies (Alabi, 1996; Aigbinode, 2008) reveal that while most telecom multinationals in Nigeria have recorded substantial success in service localization through language translations which cover multi-lingual 
services in Yoruba, Hausa and even Igbo language, GSM supported online transactions in naira equivalent and location mapping services; nonetheless, their functions and operations have often been impaired by reports of conflicts between the multinationals and host communities, tariff issues, fines due to their failure to abide by stipulated guidelines of the Nigerian Communications Commission (NCC) and other issues which have impacted on the effectiveness of their service localization (Aigbinode, 2008). These factors are considered as major setbacks for telecom multinationals in Nigeria given the multinationals exposure to a variety of expectations and operational implications (Izuchukwu, 2014).

\section{Relational Capital and Effective Service Localization}

Several studies have examined the imperative and contributions of relational capital towards the overall performance and behaviour of organizations (Robson, 2001; Ramaseshan \& Loo, 1998; Saxton, 1997). Ahuja (2000) opined that one of the fundamental benefits of strategic partnership is information and an understanding of the market trends or changes in market direction. Another scholar, Tsang (2002) observed that relational capital enhanced the organizations level of efficiency as it provided the organization with privileged information on quality sources and channels of marketing and servicing. However, Zhang et al (2008) opined that relational capital also extends to factors such as customer loyalty and employee satisfaction. This is as relationships with the customers (internal and external) often enhances the features of services with regards to noted expectations and values.

In achieving effectiveness, studies reveal that relational capital provides a strong base for market knowledge (Daum, 2003; Johson et al, 1996; Zaheer, McEvily \& Perrone, 1998). Organizations which are able to learn and gain knowledge from their counterparts which share the same context can be said to stand a better chance at effectiveness. As earlier noted, strategic partnerships facilitate not only the sharing of costs or resources in the completion of projects or goals, but also create avenues through which organizations can apply workable models and templates from other organizations. It could involve new relationships and connections with significant others within the community or access to knowledge on efficient operational modes for market changes (Zaheer et al, 1998).

Studies (Tsang, Nguyen \& Erramilli, 2004; Saxton, 1997; Roath et al, 2002; Inkpen, 2002) suggest that by growing and enriching one's business networks, firms can effectively situate themselves within the confluence of several social and market domains, generate opportunities for innovativeness and organizational change, obtain information about possible changes or restructuring within the industry and also be able to predict possible competitive trends. In this manner, multinationals such as telecommunication firms in Nigeria can stay afloat and be resilient during the challenges resulting from various changes in regulatory frameworks and operational benchmarks. Relational capital provides not only the flexibility required for adapting but also contributes to a substantial amount of stability or loyalty in the behaviour of the customers; particularly in relation to the perceived reputation or image of the firm attained through its relational capital.

\section{Conclusion}

This paper addressed the relationship between relational capital and the effectiveness of service localization in Nigeria. Central to this purpose, were three major objectives, a) the assessment of the concepts - relational capital, service localization, and effective service localization, b) the distinction between service localization and effective service localization, and c) the theoretical link between relational capital and effective service localization

Drawing from the institutional theory, this paper linked emerging benefits and advantages accruing from relationships and network membership to effective service localization. Based on the generality of theoretical positions assessed, it was affirmed that relational capital enhances multinationals capacity to sustain and serve their market given improved levels of adherence to social norms, socio-cultural conventions, regulations and local authorities.

As such, this paper concludes by stating that relational capital is imperative and enhances the extent to which firms are able to understand and appreciate the uniqueness of their foreign operational contexts, meet with the social and economic requirements of such a context and as such be consistent in their service to their foreign markets. This assertion follows the position that through strategic partnerships, enriched exchanges between the firm and its employees, suppliers, distributors and other significant network actors such as regulatory agencies, and local authorities, organizations can effectively delineate and address the social, cultural and economic concerns of their businesses and operational contexts; and by that effectively localize their services.

\section{References}

Acemoglu, D. \& Johnson, S. (2005). Unbundling institutions. Journal of Political Economy, 113, 949-995.

Ahuja, G. (2000). The duality of collaboration: Inducements and opportunities in the formation of inter-firm linkages. Strategic Management Journal, 21, 317-343.

Aigbinode R (2008). Seven years of telecoms revolution: The breath-taking revolution in telecoms industry. Tell 
magazine of Nigeria, 25-28.

Alabi, G. A. (1996). Telecommunications in Nigeria: A lecture delivered at the University of Pennsylvania African Centre, March 27

Andersen, K. V. (2013). The problem of embeddedness revisited: Collaboration and market types. Research Policy, $42,139-148$

Andersson, U., Forsgren, M. \& Holm, U. (2002). The strategic impact of external networks: Subsidiary performance and competence development in the multinational corporation. Strategic Management Journal, 23, 979-996.

Barney J. B. (2001). Is the resource-based view a useful perspective for strategic research? Academy of Management Review, 26(1).

Brouthers, K. D. \& Hennart, J.-F. (2007). Boundaries of the firm: Insights from international entry mode research. Journal of Management, 33, 395-425.

Butler J. K. Jr. (1995). Behaviour, trust and goal achievement in a win-win negotiating role play. Group \& Organization Management, 20(4).

Chan, C. M., Isobe, T. \& Makino, S. (2008). Which country matters? Institutional development and foreign affiliate performance. Strategic Management Journal, 29, 1179-1205

Christensen, C.E. (1997). The innovator's dilemma: When new technologies cause great firms to fail. Boston: Harvard Business School Press.

Coleman J. S. (1988). Social capital in the creation of human capital. American Journal of Sociology, 94.

Cui, L., Meyer, K. E. \& Hu, H. W. (2014). What drives firms' intent to seek strategic assets by foreign direct investment? A study of emerging economy firms. Journal of World Business, 49, 488-501.

Daum JH (2003). Intangible assets and value creation, John Willey and Sons, New York.

Delios, A. \& Henisz, W. J. (2003a). Political hazards and the sequence of entry by Japanese firms. Journal of International Business Studies, 34, 227-241.

Elango, B. \& Pattnaik, C. (2007). Building capabilities for international operations through networks: A study of Indian firms, Journal of International Business Studies, 38, 541-555.

Elango, B. (2009). Minimizing effects of liability of foreignness: Response strategies of foreign firms in the United States. Journal of World Business, 44, 51-62.

Eme, O. I \&. Onwuka C. C (2011). Political economy of deregulation policy in Nigeria: The challenges ahead, Journal of Business and Organizational Development, 2(1), 1-21.

Fryxell, G., Butler, J. \& Choi, A. (2004). Successful localization programs in China: An important element in strategy implementation. Journal of World Business, 39, 268- 283.

Gertler, M. S. (2003). Tacit knowledge and the economic geography of context, or the undefinable tacitness of being (there). Journal of Economic Geography, 3, 75-99.

Guler, I. \&, Guillén, M. (2010). Institutions and the internationalization of US venture capital firms. Journal of International Business Studies, 41, 185-205.

Habib, M. \& Zurawicki, L. (2002). Corruption and foreign direct investment. Journal of International Business Studies, 33, 291-307

Hassan, A. O. (2011). Telecommunications reform and effects of competition on availability, quality and cost of services in Nigeria, Public Policy and Administration Research, 1(3), 8-1

Henisz, W. J. (2000). The institutional environment for multinational investment. Journal of Law, Economics and Organization, 16, 334-364

Hennart, J. (2012). Emerging market multinationals and the theory of the multinational enterprise. Global Strategy Journal, 2, 168-187.

Holburn, G. L. F. \& Zelner, B. A. (2010). Policy risk, political capabilities and international investment strategy: Evidence from the global electric power industry. Strategic Management Journal, 31, 1290-1315.

Hyder, A. S., \& Ghauri, P. N. (2000). Managing international joint venture relationships-a longitudinal perspective. Industrial Marketing Management, 29, 205-218.

Inkpen, A. C. (2002). Learning, knowledge management, and strategic alliances: So many studies, so many unanswered questions. In F. J. Contractor \& P. Lorange (Eds.), Cooperative strategies and alliances, 267289. Amsterdam: Pergamon.

Izuchukwu O (2014). Relationship between FDI and telecommunication growth in Nigeria: Proceeding of the 7 th International Conference on Innovation Management.

Jensen, N. M. (2006). Nation-states and the multinational corporation: A political economy of foreign direct investment. Princeton, NJ: Princeton University Press. Peng, M. W. (2003). Institutional transitions and strategic choices. Academy of Management Review, 28: 275-296.

Johnson J. L. Cullen J. B., Sakano T., Takenouchi H. (1996). Setting the stage for trust and strategic integration in Japanese-Us co-operative alliances. Journal of International Business Studies, 27(5).

Joshi, A. W., \& Stump, R. L. (1999). The contingent effect of specific asset investments on joint action in 
manufacturer-supplier relationships: An empirical test of the moderating role of reciprocal asset investments, uncertainty, and trust. Journal of the Academy of Marketing Science, 27(3): 291-305.

Kale P., Dyer J, \& Singh H. (2002). Alliance capability, stock market response and long-term alliance success: The role of the alliance function. Strategic Management Journal, 23(8).

Makino, S., \& Delios, A. (1996). Local knowledge transfer and performance: Implications for alliance formation in Asia. Journal of International Business Studies, 27(5), 905-927.

Nahapiet, J., \& Ghoshal, S. (1998) Social Capital, intellectual capital, and the organizational advantage. Academy of Management Review. 23 (2).

Ramaseshan, B., \& Loo, P. C. (1998). Factors affecting a partner's perceived effectiveness of strategic business alliance: Some Singaporean evidence. International Business Review, 7(4), 443-458.

Rindfleisch, A., \& Moorman, C. (2001). The acquisition and utilization of information in new product alliances: a strength-of-ties perspective. Journal of Marketing, 65.

Roath, A. S., Miller, S. R., \& Cavusgil, S. T. (2002). A conceptual framework of relational governance in foreign distributor relationships. International Business Review, 11, 1-16.

Robson, M. J. (2001). International strategic alliance performance and inter-partner trust: An exchange theory analysis. Unpublished Ph.D. Dissertation. Cardiff, U.K.: Cardiff University.

Saxton, T. (1997). The effects of partner and relationship characteristics on alliance outcomes. Academy of Management Journal, 40(2): 443-461.

Speth J. G. (2008), The bridge at the edge of the world. Yale University Press: New Haven.

Starovic, D., \& Marr, B. (2003). Understanding corporate value: Managing and reporting intellectual capital. Retrieved http://www.cimaglobal.com/Documents/ImportedDocuments/tech_techrep_understanding_corporate_value 2003.pdf

Sveiby K. E. (2001). A knowledge-based theory of the firm to guide strategy formulation. Journal of Intellectual Capital, 2 (4)

Tsang, E. W. K. (2002). Acquiring knowledge by foreign partners from international joint ventures in a transition economy: Learning-by-doing and learning myopia. Strategic Management Journal, 23(9), 835-854.

Tsang, E. W. K., Nguyen, D. T., \& Erramilli, M. K. (2004). Knowledge acquisition and performance of international joint ventures in the transition economy of Vietnam. Journal of Information Marketing, 12(2), $82-103$

Vasileiadou E. M., Missler-Behr M. (2010). Relevance and Importance of Intellectual Capital Reporting for New Technology-Based Ventures. Proceedings of the 2nd ECIC Conference. March 29-30. Lisbon. Portugal.

Young, M.N., Tsai, T., Wang, X., Liu, S. \& Ahlstrom, D. (2014). Strategy in emerging economies and the theory of the firm. Asia Pacific Journal of Management, 31, 331- 354.

Zaheer, A., McEvily, B., \& Perrone, V. (1998). Does trust matter? Exploring the effects of interorganizational and interpersonal trust on performance. Organization Science, 9(2), 141-159.

Zhang J., Souitaris V., Soh P., \& Wong P. (2008). A contingent model of network utilization in early financing of technology ventures. Entrepreneurship Theory and Practice, 32 (4).

Zhao, Z. J. \& Anand, J. (2009). A multilevel perspective on knowledge transfer: Evidence from the Chinese automotive industry. Strategic Management Journal, 30, 959-983.

Zheng W., Yang B., \& McLean G. (2010). Linking organizational culture, structure, strategy, and organizational effectiveness: Mediating role of knowledge management. Journal of Business Research, 63(7), 763-771 